\title{
Wเḍ๋a deta
}

JURNAL ILMIAH ILMU AGAMA DAN ILMU SOSIAL BUDAYA

\section{Komunikasi Simbolik dalam Tari Pendet}

Lanang pada Usabha Sambah di Desa

Pakraman Pesedahan Kecamatan Manggis

\section{Kabupaten Karangasem}

I Gusti Ayu Ratna Pramesti Dasih

Fakultas Dharma Duta, IHDN Denpasar

Abstract

Communication can be done in a simple way to a complex way. The process of communication can be seen from the activities of social life so that the process of symbolic communications of society can be formed based on the meanings that are believed by himself then embodied with the symbols of communication. Dance Pendet Lanang acts as a communicator and village community Pakraman Pesedahan as a communicant. Communication process can occur in one direction or two way. The symbols contained in the Dance Pendet Lanang in the Village Pakraman Pesedahan has a uniqueness because the message conveyed has a sacred value that is believed and needs to be communicated to the public. Pendet Lanang Dance is one of the sacred dances that must be performed during the series of Usabha Sambah in Pakraman Pesedahan Village conducted every Purnama Fifth in accordance with the Balinese calendar system.

Keywords

Tari Pendet Lanang, Symbolic Communication, Hindu Ritual

\section{PENDAHULUAN}

Komunikasi merupakan aktivitas manusia yang penting dan esensial dalam kehidupan manusia. Komunikasi dapat dilakukan dengan cara sederhana hingga kompleks. Komunikasi bisa dilakukan secara verbal dan nonverbal. Komunikasi verbal yaitu komunikasi yang berbentuk kata-kata dalam penggunaannya, sedangkan komunikasi nonverbal adalah komunikasi tanpa katakata tetapi menggunakan isyarat atau simbol-simbol. Komunikasi yang baik dan efektif dapat dilihat dari proses komunikasinya. Proses komunikasi dapat dilihat dari aktivitas kehidupan sosialnya, sehingga pemahaman masyarakat dapat dibentuk berdasarkan makna-makna yang diyakini kemudian diwujudkan dengan simbol-simbol komunikasi. Salah satu komponen komunikasi yaitu pesan yang terkandung dalam komunikasi simbolik dapat disebarluaskan melalui 
proses komunikasi yang dilakukan oleh komunikator kepada komunikan.

Tari Pendet Lanang bertindak sebagai komunikator dan masyarakat Desa Pakraman Pesedahan Kecamatan Manggis Kabupaten Karangasem sebagai komunikan. Proses komunikasinya bisa terjadi secara satu arah ataupun dua arah. Simbol-simbol yang terdapat dalam Tari Pendet Lanang memiliki keunikan karena pesan yang disampaikan mempunyai nilai sakral yang sangat diyakini dan perlu dikomunikasi kepada masyarakat. Tari Pendet termasuk dalam jenis Tari Wali, yaitu tarian yang dipentaskan khusus saat dilaksanakan upacara keagamaan. Tari ini mengisahkan turunnya Dewi-Dewi dari kahyangan ke bumi. Meski tergolong Tari Wali namun sangat berbeda dengan tarian upacara lainnya, dimana harus memiliki penari khusus dan terlatih. Namun, dalam Tari Pendet siapapun bisa menarikannya. Tari Pendet biasanya dibawakan oleh penari putri berkelompok atau berpasangan. Ditampilkan setelah Tari Rejang menghadap ke Palinggih dengan membawa perlengkapan sesaji seperti sangku dan kendi berisi arak/tuak.

Berbeda dengan Tari Pendet pada umumnya, Desa Pakraman Pesedahan Kecamatan Manggis Kabupaten Karangasem memiliki keunikan yakni Tari Pendet Lanang karena ditarikan oleh lanang (laki-laki) yang tergabung dalam sekaa truna. Tari Pendet Lanang ini dipentaskan saat dilaksanakan upacara Usabha Sambah dan sangat disakralkan oleh masyarakat setempat karena sarat dengan keunikankeunikan. Penari pada Tari Pendet Lanang merupakan sekaa truna yang mana diawali oleh truna desa murwa yaitu sekaa truna yang merupakan penduduk asli desa, kemudian dilanjutkan oleh para pengayah lainnya. Setiap aktivitas manusia sarat akan simbol didalamnya. Demikian juga dengan pementasan Tari Pendet Lanang, yang memiliki makna dari setiap simbol sarana yang dibawa dan setiap gerak tarinya.

\section{PEMBAHASAN}

Tari Pendet Lanang merupakan salah satu tari sakral yang wajib dipentaskan saat dilaksanakan rangkaian Usabha Sambah di Desa Pakraman Pesedahan yang dilaksanakan setiap Purnama Kelima, terdapat beberapa tahapan upacara dengan maksud agar upacara yang dilangsungkan terhindar dari segala macam masalah dan masyarakat merasa tidak terbebani. Pembahasan tentang keberadaan Tari Pendet Lanang pada Usabha Sambah di Desa Pakraman Pasedahan dapat diuraikan sebagai berikut :

\section{Riwayat Tari Pendet di Bali}

Tari Pendet adalah jenis tari pemujaan yang ditarikan di Pura. Tari ini menggambarkan penyambutan atas turunnya Dewa-Dewa ke Marcapada. Tari Pendet termasuk dalam jenis tari wali yaitu tarian Bali yang dipentaskan khusus untuk keperluan upacara keagamaan. Tarian ini diciptakan oleh seniman tari Bali yang bernama I Nyoman Kaler pada tahun 1970-an yang bercerita tentang turunnya Dewi-Dewi Kahyangan ke bumi. Meski tarian ini tergolong ke dalam jenis tari wali, namun berbeda dengan tarian upacara lain yang biasanya memerlukan para penari khusus dan terlatih. Untuk Tari Pendet siapapun bisa menarikannya, baik yang sudah terlatih maupun yang masih awam dan biasanya ditarikan para wanita. 
Pada awalnya, Tari Pendet merupakan tari pemujaan yang banyak dipentaskan di Pura, dengan gambaran penyambutan atas turunnya Dewa-Dewi ke alam Marcapada, dan merupakan pernyataan persembahan dalam bentuk tarian upacara. Lambat laun seiring perkembangan zaman, para seniman tari Bali mengubah Tari Pendet menjadi tari "Ucapan Selamat Datang", dilakukan sambil menaburkan bunga di hadapan para tamu yang datang seperti halnya Aloha di Hawaii. Kendati demikian bukan berarti Tari Pendet jadi hilang kesakralannya. Tari Pendet tetap mengandung nilai sakral-religius dengan menyertakan muatan-muatan keagamaan yang kental, Tari Pendet disepakati lahir pada tahun 1950.

Pementasan Tari Pendet memerlukan beberapa macam perlengkapan busana dan juga properti. Adapun macam-macam perlengkapan busana dan properti Tari Pendet adalah 1) sabuk prada, 2) anteng, 3) kain songket, dan 4) bokor. Tari Pendet mempunyai peran sebagai tari wali dan bentuk tariannya adalah tari berkelompok. Tari Pendet dibawakan secara berkelompok atau berpasangan oleh para putri dan gerakannya lebih dinamis dari Tari Rejang. Biasanya ditampilkan setelah Tari Rejang di halaman Pura dan menghadap ke arah Palinggih. Para penari Pendet berdandan layaknya para penari upacara keagamaan yang sakral lainnya, dengan memakai pakaian upacara masingmasing penari membawa perlengkapan sesajen persembahan seperti sangku, kendi, cawan dan yang lainnya.

Wayan Dibia seorang Guru Besar Institut Seni Indonesia (ISI) Denpasar, menegaskan bahwa Tari Pendet sudah sejak lama menjadi bagian yang tidak terpisahkan dari kehidupan spiritual masyarakat Hindu di Bali. Tarian ini merupakan tarian yang dibawakan oleh sekelompok remaja putri, masingmasing membawa bokor yang penuh berisi bunga. Pada akhir tarian para penari menaburkan bunga ke arah penonton sebagai ucapan selamat datang. Tarian ini biasanya ditampilkan untuk menyambut tamu-tamu atau memulai suatu pertunjukkan. Pencipta atau koreografer bentuk modern Tari Pendet ini adalah I Wayan Rindi (1967) merupakan penari yang dikenal luas sebagai penekun seni tari dengan kemampuan mengubah tari dan melestarikan seni tari Bali melalui pembelajaran pada generasi penerusnya. Semasa hidupnya aktif mengajarkan beragam tari Bali, termasuk Tari Pendet kepada keluarga maupun masyarakat sekitarnya.

\section{Usabha Sambah di Desa Pakraman Pesedahan Kecamatan Manggis Kabupaten Karangasem}

Usabha merupakan bentuk dari pelaksanaan yajna yang dilaksanakan oleh masyarakat Hindu di Bali, khususnya dalam Desa Adat sebagai upaya dan usaha menghubungkan diri kepada Ida Sang Hyang Widhi Wasa dengan segenap manifestasinya. Usabha sering diidentikkan dengan kata Odalan. Di Kabupaten Karangasem perayaan upacara keagamaan yang biasanya dilaksanakan setiap satu tahun sekali sering disebut Usabha, sedang diluar daerah Karangasem sering disebut dengan Odalan. Pura Kahyangan Tiga yakni Pura Desa, Pura Puseh dan Pura Dalem, perayaan upacara dilaksanakan setahun sekali dimasing-masing Pura disebut dengan Usabha Desa, Usabha Sambah dan Usabha Dalem. 
Dalam Kamus Bali Indonesia disebutkan bahwa kata Usabha berasal dari Bahasa Jawa Kuno yang mengandung arti perayaan, pesta atau perjamuan. Terkait dengan upacara keagamaaan kata Usabha dapat diartikan sebagai suatu perayaan atau pesta perjamuan kehadapan Ida Sang Hyang Widhi Wasa dalam bentuk persembahan berupa berbagai hasil bumi sebagai ungkapan rasa terima kasih dan rasa syukur kehadapan beliau atas segala anugrahnya kepada seluruh ciptaan-Nya di alam semesta. Selanjutnya, kata Sambah dalam Kamus Jawa Kuno-Indonesia mengandung arti sembah atau memuja (Zoetmulder, 2005:999). Kata Sambah berasal dari kata "se dan embah", dimana se artinya satu dan embah artinya perayaan. Maka yang dimaksud upacara Usabha Sambah adalah perayaan keagamaan yang dilakukan oleh umat Hindu di Bali, khususnya masyarakat Desa Pakraman Pesedahan untuk memuja Ida Sang Hyang Widhi Wasa pada satu tempat atau sthana Tuhan. Sthana yang dimaksud khusus bagi masyarakat Desa Pakraman Pesedahan yaitu sanggar surya. Sanggar surya terbuat dari pelepah kayu enau berkaki enam, dengan rong satu berundak dua yang dilengkapi dengan upakara-upakara. Upakara dimaksud seperti berbagai daun-daunan yakni daun enau muda (ambu) dan hasil bumi lainnya yang dihasilkan oleh masyarakat Desa Pakraman Pesedahan sebagai bentuk persembahan yang tulus ikhlas kepada Ida Sang Hyang Widhi Wasa, seperti : pala gantung, pala bungkah, pala wija, jenis-jenis jajan sebagai ungkapan rasa terima kasih dan rasa syukur telah dilimpahkan kepada semua ciptaan-Nya. Pemujaan atau persembahyangan dilaksanakan pada sthana Ida Sang Hyang Widhi Wasa yang disebut Sang Hyang Sambah. Tujuannya untuk memohon keselamatan dan kesejahteraan agar tercipta keseimbangan alam sehingga terwujud suasana yang penuh kedamaian. Upacara Usabha Sambah dilaksanakan setahun sekali tepatnya pada Purnama Sasih Kelima menurut kalender Bali.

\section{Tari Pendet Lanang di Desa Pakraman Pesedahan Kecamatan Manggis Kabupaten Karangasem}

Tari Pendet pada umumnya ditarikan oleh kaum wanita dalam suatu upacara keagamaan umat Hindu di Bali. Hanya saja, di Desa Pakraman Pesedahan terdapat suatu keunikan dimana Tari Pendet di desa ini ditarikan oleh kaum laki-laki yang telah mengalami akil balik dan belum menikah. Tari Pendet Lanang dalam Usabha Sambah di Desa Pakraman Pesedahan merupakan suatu bentuk perpaduan seni gerak dan irama gamelan yang khas berhubungan dengan upacara keagamaan yang dalam hal ini upacara Usabha Sambah di Desa Pakraman Pesedahan. Tari Pendet Lanang ditarikan oleh sekaa truna dari Desa Murwa (warga asli setempat) yang menggunakan pakaian sebatas dada.

\section{Sarana dan Busana dalam Pementasan Tari Pendet Lanang di Desa Pakraman Pesedahan Kecamatan Manggis Kabupaten Karangasem}

Pementasan Tari Pendet Lanang dalam Usabha Sambah yang dipentaskan oleh sekaa truna Desa Murwa (mudamudi desa asli) mulai dari umur 12 tahun dan yang belum menikah. Dimana saat pementasan terdiri dari 3 (tiga) barisan yang masing-masing barisan terdiri dari 7 (tujuh) orang. Dipilihnya sekaa truna dalam pementasan ini sebagai suatu 
pendidikan guna membiasakan generasi muda agar tetap aktif mengikuti upacara keagamaan, disamping sekaa truna dianggap masih suci karena belum menikah. Para penari Tari Pendet Lanang ini membawa sarana upacara saat pementasan berlangsung. Sarana upacara itu terdiri dari : klungah pada posisi pertama sebagai sarana penyucian, diposisi kedua membawa canang rawis sebagai persembahan berupa bunga-bunga harum serta diposisi ketiga membawa sanganan (banten) yang dipersembahkan dari hasil bumi yang ada di daerah setempat. Klungah dipergunakan adalah klungah yang telah dikasturi. Klungah yang dimaksud adalah buah kelapa yang masih muda yang didalamnya belum berisi daging hanya berisi air saja. Klungah tersebut dikasturi atau dilubangi namun penutupnya tidak dilepas dan dilengkapi dengan canang dan tempat untuk membawanya. Canang rawis, terbuat dari daun kelapa yang masih muda atau sering disebut dengan busung, diringgit didalamnya dilengkapi dengan pelawa (daun kayu), porosan (daun sirih yang diisi dengan kapur dilipat dengan busung), cerawis dan diatasnya dilengkapi dengan bunga. Sanganan terdiri dari sesajen kecil yang didalamnya berisi pisang, buah dan jajanan khas Bali, kacang, saur, telur dan diatasnya diisi dengan canang reta.

Setiap pementasan tari pastinya memiliki ciri khas serta memiliki unsur tradisional setempat sesuai dengan garapan tari tersebut. Busana dan tata rias yang dipakai dalam pentas merupakan suatu alat untuk membantu penokohan. Khusus pada Tari Pendet Lanang, busana yang digunakan sangat sederhana yaitu terdiri dari : 1) Kain (kamben) sebatas pusar keatasnya, melancingan ciri laki-laki; 2) Saput, tingginya sebatas dada; 3) Umpal atau sabuk pengikat di dada; 4) Udeng walaka (mejenggeran). Busana yang digunakan merupakan kebiasaan turun-temurun yang diwarisi dari dulu hingga sekarang. Kain yang digunakan harus ada lancingannya serta dilipat dari kanan ke kiri. Tidak ada yang berani merubah tata busana Tari Pendet Lanang ini karena merupakan warisan budaya dari leluhur. Rias wajah (make-up) tidak terlalu ditonjolkan, hal ini dikarenakan tarian ini hanya ditujukan untuk hal yang bersifat ritual bukan bersifat seni pertunjukkan. Maka, dapat dilihat bahwa tata rias dan tata busana Tari Pendet Lanang dalam rangkaian Usabha Sambah di Desa Pakraman Pesedahan sangatlah sederhana sesuai dengan tuntutan upacara yang diselenggarakan.

\section{Gamelan dan Jenis Gerak Tari Pendet Lanang dalam Usabha Sambah di Desa Pakraman Pesedahan Kecamatan Manggis Kabupaten Karangasem}

Suatu pertunjukkan tari selalu diiringi oleh gamelan yang berkaitan antara gerak tari dan musik gamelan. Pementasan Tari Pendet Lanang diiringi oleh gong dengan gending atau tabuh Pendet Lanang. Penari harus mengikuti irama dan angsel gong dalam melakukan gerak, misalnya saat jalan nayog, ngembat dan ngejit bahu. Gending tabuh dan Tari Pendet Lanang ini hanya ada di Desa Pakraman Pesedahan dan hanya dimainkan saat dilaksanakannya Usabha Sambah dan odalan pada pura-pura di lingkungan Desa Pakraman Pesedahan. Tari Pendet Lanang menjadi salah satu tari wali yang wajib dipentaskan saat dilaksanakannya Usabha atau Odalan di pura-pura wilayah Desa Pakraman Pesedahan. 
Khusus pada pementasan tari ini, gerak tari yang dipakai adalah gerakan agem kanan dan agem kiri, jalan nayog sambil memegang sarana upakara sebatas bahu disertai tanjek, seledet, dan ngembat tangan kiri ke samping. Tari Pendet Lanang ini menggunakan gerakan yang sederhana layaknya tari kuno (klasik), berbeda dengan tari modern (kreasi baru) yang lebih menonjolkan kreativitas gerak yang indah. Walaupun gerak yang dipergunakan sangat sederhana tetapi memiliki makna yang sangat suci bagi masyarakat di Desa Pakraman Pasedahan.

\section{Fungsi Pementasan Tari Pendet Lanang} Dalam Usabha Sambah di Desa Pakraman Pesedahan Kecamatan Manggis Kabupaten Karangasem

Tari Pendet Lanang dipentaskan di Pura Puseh pada Jaba Tengah atau Madya Mandala saat penyujukan, pebarisan dan penyuud atau pengusan. Selain di Pura Puseh, tari ini juga dipentaskan di Pura Petilaan saat Purnama Kedasa, di Pura Rambut Petung saat Manis Galungan, di Pura Pemastuan saat Purnama Kapat, di Pura Dadia dan Pemaksan yang disesuaikan dengan piodalan di pura tersebut. Jika dilihat dari segi waktu pementasan, Tari Pendet Lanang dipentaskan sebelum persembahyangan dimulai bersamaan dengan pementasana Tari Rejang Lilit, Rejang Dewa dan Sramanan. Tari Pendet Lanang mendapat giliran kedua setelah Tari Rejang Lilit.

Terkait dengan kehidupan beragama, seni merupakan pemujaan yang artinya sesuatu yang dihaturkan kehadapan Ida Sang Hyang Widhi Wasa. Seperti halnya Tari Pendet Lanang, yang merupakan suatu wujud kesenian yang dipersembahkan kehadapan Ida Sang
Hyang Widhi Wasa dan digunakan sebagai tari yang mengiringi upacara keagamaan dalam Usabha Sambah di Desa Pakraman Pesedahan. Tari Pendet Lanang tidak diperkenankan untuk dipentaskan di luar Upacara Dewa Yadnya, maka dapat diklasifikasikan bahwa Tari Pendet Lanang di Desa Pakraman Pesedahan sebagai tari sakral (sacral religious dance) yang berfungsi sebagai tari ritual. Secara umum, fungsi Tari Pendet Lanang di Desa Pakraman Pesedahan dalam rangkaian Usabha Sambah adalah untuk melatih diri dan membentuk sifat baik dengan melakukan sesuatu dengan kehendak dari Ida Sang Hyang Widhi Wasa dalam meraih kebahagiaan hidup sekarang dan yang akan datang.

\section{Fungsi Religius}

Fungsi religius Tari Pendet Lanang pada Usabha Sambah di Desa Pakraman Pesedahan adalah sebagai persembahan kepada Ida Sang Hyang Widhi Wasa dengan segala manifestasinya yang dipuja saat Usabha Sambah guna menciptakan keharmonisan, keselarasan, keseimbangan atas segala anugerah yang diberikan oleh-Nya melalui pengabdian umatnya yang didasari ketulusikhlasan.

\section{Fungsi Sosial}

Pelaksanaan Tari Pendet Lanang
dalam Usabha Sambah di Desa
Pakraman Pesedahan merupakan
wahana dalam berinteraksi sosial antara
masyarakat, penari dan warga setempat.
Manusia diajarkan untuk membina
hubungan baik sesama manusia. Begitu
pula Tari Pendet Lanang sebagai sarana
persembahan yang dapat pula dijadikan
sebagai pemupuk persatuan dan
kerukunan antarwarga di Desa


Pakraman Pesedahan yang beragama Hindu. Meskipun pementasan Tari Pendet Lanang pada Usabha Sambah dapat dinikmati oleh masyarakat, namun tidak mengurangi kesakralan ritual yang dilaksanakan. Fungsi sosial terlihat ketika pementasaan tari ini, yakni pada saat sekaa truna berkumpul dan bersatu melakukan tarian tersebut sehingga terjalin persahabatan sebagai makhluk sosial. Pementasan Tari Pendet Lanang di Desa Pakraman Pesedahan saat Usabha Sambah ini dapat memberikan dampak positif terhadap seluruh warga karena mampu menumbuhkan serta menguatkan kesetiaan, keutuhan dan kekeluargaan karena adanya rasa saling memiliki.

\section{Fungsi Seni atau Estetika}

Gerak tari serta gamelan yang mengiringinya akan memberikan nilai estetika atau seni bagi penari dan orang yang melihatnya. Pementasan Tari Pendet Lanang di Desa Pakraman Pesedahan dalam rangkaian Usabha Sambah merupakan suatu hasil olah gerak yang mencerminkan seni serta keindahan. Terkait dengan fungsi estetika dalam Tari Pendet Lanang dapat memberikan nilai seni dan keindahan khususnya untuk masyarakat setempat dan dapat memberikan inspirasi kepada seniman Bali pada umumnya.

\section{Komunikasi Simbolik dalam Tari Pendet Lanang pada Usabha Sambah di Desa Pakraman Pesedahan Kecamatan Manggis Kabupaten Karangasem}

Komunikasi sangat vital karena sebagai sumber informasi yang didapat dari proses interaksi. Komunikasi merupakan suatu transaksi, proses simbolik yang menghendaki orang mengatur lingkungannya dengan : 1) membangun hubungan dengan antar sesama manusia; 2) melalui pertukaran informasi; 3) untuk menguatkan sikap dan tingkah laku orang lain; dan 4) berusaha mengubah sikap dan tingkah laku itu. Komunikasi adalah suatu proses dimana seseorang atau beberapa orang, kelompok, organisasi, dan masyarakat menciptakan dan menggunakan informasi agar terhubung dengan lingkungan dan orang lain. Pada umumnya, komunikasi dilakukan secara lisan atau verbal yang dapat dimengerti oleh kedua belah pihak. Apabila tidak ada bahasa verbal yang dapat dimengerti oleh keduanya, komunikasi masih dapat dilakukan secara nonverbal dengan menggunakan isyarat seperti gesture, menunjukkan sikap tertentu, misalnya tersenyum, menggelengkan kepala, mengangkat bahu (Effendy, 2003:35).

Proses komunikasi dapat membangun hubungan dengan sesama manusia, melalui pertukaran informasi dan menguatkan sikap serta tingkah laku orang lain. Anderson menyatakan komunikasi adalah proses di mana individu saling memahami dan dipahami. Selanjutnya Ruesch dan Beteson menyatakan komunikasi tak sematamata merujuk pada transmisi peran verbal, eksplisit dan intensional tetapi juga meliputi segala proses dimana seseorang mempengaruhi yang lain (dalam Santoso, 2010:5). Pemahaman komunikasi adalah sebuah proses dimana seseorang mengurangi ketidakpastian melalui isyarat yang terdeteksi dalam sebuah hubungan. Tari Pendet Lanang menggunakan interaksi yang terjalin menjadi tataran teoritis, paling tidak mengenal atau memahami komunikasi dari dua perspektif, yaitu perspektif kognitif dan perilaku. Komunikasi mewakili perspektif kognitif 
adalah penggunaan lambang-lambang (simbolis) untuk mencapai kesamaan makna atau berbagai informasi tentang satu objek atau kejadian. Informasi adalah suatu fakta, opini, gagasan dari satu partisipan kepada partisipan lain melalui penggunaan kata-kata atau lambang lainnya didalam pelaksanaan pementasan Tari Pendet Lanang pada Usabha Sambah di Desa Pakraman Pesedahan. Jika pesan yang disampaikan diterima secara akurat, maka akan memiliki informasi yang penting dalam mencapai tujuan yang diinginkan, oleh karena itu proses komunikasi menjadi suatu penentu keberhasilan dalam pementasan Tari Pendet Lanang.

Komunikasi nonverbal pada Tari Pendet Lanang nampak melalui simbolsimbol komunikasi dengan menggunakan berbagai bahasa isyarat. Bahasa isyarat dapat terlihat dalam penggunaan banten sebagai perwujudan dari Ida Sang Hyang Widhi Wasa itu sendiri. Manusia dalam berkomunikasi selain memakai kode verbal (bahasa) juga memakai kode nonverbal. Kode nonverbal biasa disebut bahasa isyarat atau bahasa diam (silent lenguage). Mark Knapp menyebutkan bahwa penggunaan kode nonverbal dalam berkomunikasi memiliki fungsi untuk : 1) meyakinkan apa yang diucapkannya (repetition); 2) menunjukkan perasaan atau emosi yang tidak ditunjukan dengan kata-kata (substitution); 3) menunjukkan jati diri sehingga orang lain bisa mengenalnya (identity); dan 4) menambah atau melengkapi ucapanucapan yang dirasakan belum sempurna (dalam Cangara, 2010: 104).

Komunikasi nonverbal dalam pementasan Tari Pendet Lanang pada Usabha Sambah tercermin dengan adanya keyakinan masyarakat di Desa
Pakraman Pesedahan terhadap simbolsimbol yang digunakan dalam pementasan. Simbol-simbol yang dimaksud adalah suatu barang atau benda yang diyakini oleh masyarakat sebagai perlambang dari perwujudan $I d a$ Sang Hyang Widhi Wasa seperti klungah, canang rawis, dan sanganan. Proses komunikasi nonverbal terjadi saat banten, kelungah, canang rawis, dan sanganan yang dibawa oleh penari saat pementasan Tari Pendet Lanang pada Usabha Sambah. Komunikasi simbolik dalam Tari Pendet Lanang pada Usabha Sambah di Desa Pakraman Pesedahan adalah sarana upakara yang dibawa oleh para penari saat menarikan Tari Pendet Lanang antara lain : klungah, canang rawis, dan sanganan. Hal ini sangat perlu untuk dipahami sehingga masyarakat di Desa Pakraman Pesedahan paham apa yang dilaksanakannya, apa tujuan serta fungsinya sehingga gugon tuon atau mule keto tidak lagi menjadi bahasa yang diturunkan kepada generasi penerusnya. Komunikasi simbolik merupakan upaya mengkomunikasikan makna yang terkandung dalam klungah, canang rawis, dan sanganan yang digunakan sebagai sarana dalam pementasan Tari Pendet Lanang. Komunikasi simbolik juga berfungsi untuk mengkomunikasi makna-makna tersebut kepada masyarakat agar dipahami dan dilestarikan.

Pementasan Tari Pendet Lanang pada Usabha Sambah di Desa Pakraman Pesedahan sebagai berikut : penari Tari Pendet Lanang yang merupakan truna murwa menggunakan pakaian adat tanpa menggunakan baju sedangkan pengayah yang ikut berpartisipasi menarikan Tari Pendet Lanang menggunakan pakaian adat namun tetap menggunakan baju. Disini akan terlihat 
jelas perbedaanya antara truna murwa dengan sekaa truna lainnya. Truna murwa harus berada di depan dengan membawa sarana upakara seperti klungah, canang rawis dan sanganan sedangkan sekaa truna lainnya yang ikut ngayah berbaris dibelakangnya. Klungah dibawa oleh penari pada urutan paling pertama memiliki makna sebagai sarana penyucian. Berikutnya canang rawis dibawa oleh penari berisi persembahan bunga-bunga harum, yang memiliki makna sebagai wujud rasa cinta kasih agar semua yang ada di dunia menjadi indah (ngias). Selanjutnya sanganan yang dibawa oleh penari memiliki makna sebagai bentuk persembahan dan rasa terima kasih karena hasil bumi yang diterima berlimpah.

Proses komunikasi simbolik Tari Pendet Lanang berawal dari adanya proses interaksi yang dilaksanakan dari generasi ke generasi. Interaksi merupakan terjalinnya komunikasi antara manusia untuk menyampaikan pesan yang ingin disampaikan. Dalam hal ini adalah Tari Pendet Lanang, yang harus dipahami oleh masyarakat di Desa Pakraman Pesedahan. Pementasan Tari Pendet Lanang di Desa Pakraman Pesedahan diyakini berfungsi untuk memberi keharmonisan dalam kehidupan masyarakat setempat.

\section{PENUTUP}

Tari Pendet Lanang merupakan suatu bentuk perpaduan seni gerak dan nada yang berhubungan dengan upacara keagamaan, dalam hal ini upacara Usabha Sambah di Desa Pakraman Pesedahan. Tarian ini ditarikan oleh sekaa truna dari Desa Murwa (warga asli setempat) yang menggunakan pakaian sebatas dada. Tari Pendet Lanang ini ditarikan oleh kaum laki-laki yang belum menikah. Karena para remaja yang belum menikah masih dianggap suci. Proses komunikasi simbolik Tari Pendet Lanang nampak pada interaksi yang terjalin dalam masyarakat, untuk menjaga keharmonisan antarmanusia, alam beserta segala isinya agar terhindar dari segala macam malapetaka (kebebrehan) serta dapat meningkatkan kesejahteraan masyarakat baik secara spiritual maupun ekonomi. Komunikasi Simbolik dalam Tari Pendet Lanang adalah digunakannya sarana atau simbol-simbol berupa benda yang diyakini memiliki makna serta maksud untuk memuja kebesaran Ida Sang Hyang Widhi Wasa seperti banten, klungah, canang rawis dan sanganan yang berfungsi untuk mengharmonisasikan bhuana agung dan bhuana alit.

\section{DAFTAR PUSTAKA}

Cangara, Hafied. 2009. Pengantar Ilmu Komunikasi. Jakarta : PT. Raja Grapindo Persada

Effendy, O. Uchjana. 2004. Ilmu Teori dan Filsafat Komunikasi. Bandung : Pt Citra Aditya Bakti

2007. IImu Komunikasi Teori dan Praktek. Bandung : PT. Remaja Rosdakarya

Haryanto, Sindung. 2012. Spektrum Teori Sosial : Dari Klasik Hingga Postmodern. Jogjakarta : Ar-Ruzz Media

Rakhmat, Jalaludin. 2008. Psikologi Komunikasi. Bandung: PT. Remaja Rosdakarya

Mulyana, Deddy. 2011. Metode Penelitian Kualitatif Paradigma 
Baru IImu Komunikasi dan IImu Sosial Lainnya. Bandung: PT. Remaja Rosdakarya

2010. Ilmu Komunikasi Suatu Pengantar. Bandung : PT Remaja Rosdakarya

Widjaja, H.A.W. 2010. Komunikasi dan Hubungan Masyarakat. Jakarta : Bumi Aksara 